\title{
ROBO1 wt Allele
}

National Cancer Institute

\section{Source}

National Cancer Institute. ROBO1 wt Allele. NCI Thesaurus. Code C126589.

Human ROBO1 wild-type allele is located in the vicinity of 3p12 and is approximately 1170 $\mathrm{kb}$ in length. This allele, which encodes roundabout homolog 1 protein, plays a role in both axon guidance and neuroblast migration. 